\title{
Characterization of verdete rock as a potential source of potassium ${ }^{1}$
}

\author{
Wedisson Oliveira Santos*2, Edson Marcio Mattiello ${ }^{3}$, Liovando Marciano da Costa ${ }^{4}$, \\ Walter Antônio Pereira Abrahão \\ http://dx.doi.org/10.1590/0034-737X201562040009
}

\begin{abstract}
Potassium is a nutrient found at low levels in Brazilian soils, requiring large inputs of fertilizers to achieve satisfactory crop yields. Brazil has high external dependence and limited reserves of soluble $\mathrm{K}$ mineral, which is traditionally exploited for the production of fertilizers. On the other hand, it is common the occurrence in the country of potassium-rich silicate minerals which are not commercially exploited. This study aimed to characterize mineralogically and chemically samples of verdete rock separated into size fractions and evaluate its potential as potassium fertilizer. The mineral composition of verdete rock is based on glauconite, quartz and feldspar. The total $\mathrm{K}_{2} \mathrm{O}$ content in verdete rock ranged from 5.18 to $9.0 \mathrm{dag} / \mathrm{kg}$. The $\mathrm{K}$ content extracted in water or $2 \%$ citric acid was $2.4 \%$ below the total of $\mathrm{K}$, indicating low reactivity of verdete rock and limitations for direct use as $\mathrm{K}$ source. The processes of physical fractionation and sedimentation in water are inefficient to promote the concentration of $\mathrm{K}$ in the different verdete rock fractions. The total $\mathrm{K}$ content in some samples are considerable and may enable the use of this rock as raw material for production of more reactive potassium fertilizers.
\end{abstract}

Key words: glauconite, $\mathrm{K}$, fertilizer.

\section{RESUMO}

\section{Caracterização do verdete como fonte potencial de potássio}

O K é um nutriente encontrado em baixos teores em solos brasileiros, sendo necessário grande aporte via fertilização para alcançar produtividades satisfatórias das culturas. O Brasil apresenta elevada dependência externa e possui limitadas reservas de minerais solúveis de $\mathrm{K}$, tradicionalmente explorados para a produção de fertilizantes. Por outro lado, é comum a ocorrência no país de minerais silicatados ricos em K não explorados comercialmente. Neste trabalho, objetivou-se caracterizar mineralógica e quimicamente amostras de verdete, separadas em frações granulométricas e avaliar seu potencial de uso com fertilizante potássico.A composição mineral do verdete é à base de glauconita, quartzo e feldspatos. Os teores totais de $\mathrm{K}_{2} \mathrm{O}$ no verdete variaram de 5,18 a 9,0 dag $/ \mathrm{kg}$. O teor de $\mathrm{K}$ extraído em água ou em ácido cítrico a $2 \%$ foi inferior a $2,4 \%$ do $\mathrm{K}$ total, indicando baixa reatividade do verdete $\mathrm{e}$ limitações para seu uso direto como fonte de $\mathrm{K}$. O fracionamento físico e a sedimentação em água são processos ineficientes para promover a concentração de $\mathrm{K}$ nas diferentes frações do verdete. Os teores totais de $\mathrm{K}$ em algumas amostras de verdete são consideráveis, podendo viabilizar o uso desta rocha como matéria prima para produção de fertilizantes potássicos mais reativos.

Palavras- chave: glauconita, K, fertilizante.

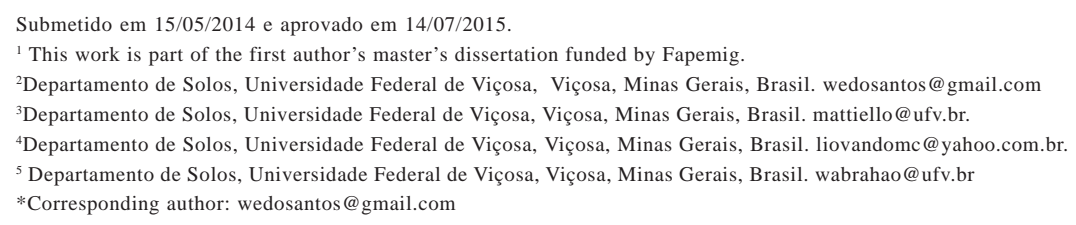




\section{INTRODUCTION}

The limited supply of soluble K minerals in the world and the growing consumption of this nutrient have been constant concerns for importing countries of potash fertilizers and agricultural importance such as Brazil, USA, China and India. The exploitation of evaporite deposits, especially salts of $\mathrm{K}$ (sylvite), $\mathrm{K}$ and $\mathrm{Na}$ (sylvite) or $\mathrm{K}$ and $\mathrm{Mg}$ (carnallite), is the main source of potassium fertilizers, as salts derived from these deposits are water soluble and can be mined and processed more easily. These deposits occur primarily in Canada, Russia, Belarus and Germany, which together account for about $85 \%$ of world exports of K (Fertecon, 2013; Oliveira, 2012).

Potash fertilizer import was higher than $90 \%$ of Brazil's domestic consumption in 2011 (Oliveira, 2012), and the country was the world's third largest consumer of these products (IFA, 2013). Low domestic production of these fertilizers is mainly due to the limited occurrence of reserves of soluble $\mathrm{K}$ salts, besides the high cost, operational difficulties and environmental risks of exploitation. This is the case of carnallite and sylvite in the states of Sergipe and Amazonas, respectively (Oliveira \& Sousa, 2001). These facts hinder the $\mathrm{K}$ commercial production in the country, which is unique in South America, with only one mine in Sergipe exploiting sylvite.

The offer and the price of potash fertilizers, as occurred in 2008, could jeopardize the expansion of Brazilian agriculture more than any other nutrient. This has stimulated the search for unconventional sources of $\mathrm{K}$ such as potassium silicate. In India, the nonoccurrence of commercially exploitable soluble $\mathrm{K}$ sources have led to exploration and research into rocks consisting mainly of glauconite (Rawlley, 1994; Rao et al., 1993), with reserves estimated at $940 \mathrm{Mt}$ (million metric ton) (Mazumder et al., 1993). In New Zealand, the occurrence of glauconite in underwater platform, with reserves estimated at $2 \mathrm{Gt}$ (billion metric ton), has raised the interest in the exploitation for the production of potassium fertilizer (Lawless, 2012).

In Brazil, alternative sources of $\mathrm{K}$ have been studied to be used as potassium fertilizers or as raw materials for their production, including nepheline syenite and feldspar (Faquin, 1982; Siqueira \& Guedes, 1986; Nascimento, 2004; Orioli Junior \& Coutinho, 2009), granite (Piza et al., 2010) and verdete rock (Lopes et al., 1972; Eichler, 1983; Santos, 1984; Leite, 1985; Piza et al., 2010, 2011).

Verdete rock, a sedimentary rock, stands out among the potential $\mathrm{K}$ sources, with variable composition and $\mathrm{K}_{2} \mathrm{O}$ content ranging from 5 to $15 \mathrm{dag} / \mathrm{kg}$ (Loureiro et al., 2010). It occurs in Serra da Saudade, Alto Paranaíba Region (MG), geologically located in the San Francisco craton (Valarelli et al., 1993). According to Eichler (1983), assessments made by METAMIG indicated, only in the municipality of Cedro do Abaeté, MG, a total of $57 \mathrm{Mt}$ of verdete rock, with an average content of 11.4 $\mathrm{dag} / \mathrm{kg} \mathrm{K}_{2} \mathrm{O}$.

Glauconite is the main potassium mineral present in verdete rock (Piza et al., 2010). According to Fassbender (1975), it is a mica of the illite group, which is characterized by having greater isomorphous substitution of $\mathrm{Al}^{3+}$ by $\mathrm{Fe}^{2+}$ in octahedral structures. This mineral is formed by a process called glauconitization, which occurs in a marine environment of slow sedimentation under reducing conditions. During this process, in low dentritic input conditions, there is loss of alumina and silica along with Fe and K enrichment (Pettijohn, 1963; Fassbender, 1975; Lima et al., 2007).

In the Bambui formation, the site for verdete rock in Brazil, glauconite gives the green color to this rock, usually with a particle size less than $3 \mu \mathrm{m}$. Stratigraphically, glauconite occurs in areas below the sedimentary input, and its genesis occurred slow halmirolysis within a reducing microenvironment (Guimarães, 1997). In the glauconitization process, the starting material resembles an iron aluminosilicate subsaturated with alkali, similar to smectites (Lima et al., 2007).

The exploitation and regional use of less reactive potassium minerals found in the country can benefit the agricultural sector with an essential nutrient input and promote the development of local mining industries. In this sense, the characterization of rocks containing $\mathrm{K}$ and knowledge of the variability of the nutrient in these materials are critical to planning processes and fertilizer production routes. Thus, this study aimed to characterize mineralogically and chemically samples of verdete rock and evaluate a physical method for concentrating $\mathrm{K}$.

\section{MATERIALAND METHODS}

This study was conducted in laboratory conditions, at the Department of Soil of the Federal University of Viçosa, using verdete rock as a potassium source.

\section{Sample collection and preparation}

Fourteen (14) samples of verdete rock were collected in the Central Region of Minas Gerais (MG), in the municipalities of Cedro do Abaeté and Quartel Geral. Sample collection was performed randomly in the landscape, from outcrops of this rock. Picks were used to break the rock, and approximately $10 \mathrm{~kg}$ of verdete rock was collected from different sites, which were 
georeferenced. The location of the collection points and their coordinates are shown in Table 1 and Figure 1, respectively.

\section{Chemical Characterization}

The chemical characterization of verdete rock samples was carried out with $0.300 \mathrm{~g}$ of rock with particle size smaller than $0.074 \mathrm{~mm}$. The samples were transferred to microwave tubes and added of $4.0 \mathrm{~mL}$ of $\mathrm{HCl}, 9.0 \mathrm{~mL}$ of $\mathrm{HNO}_{3}$ and $4.0 \mathrm{~mL}$ of HF. Next, $2.0 \mathrm{ml}$ of saturated solution of $\mathrm{H}_{3} \mathrm{BO}_{3}(100 \mathrm{~g} / \mathrm{L})$ was added. Samples were taken to the microwave, which carried out the digestion by the EPA method 3052 (1996). The extract was filtered through quantitative filter paper by rapid filtration. $\mathrm{Fe}, \mathrm{Al}, \mathrm{Ca}, \mathrm{Mg}, \mathrm{Na}, \mathrm{P}, \mathrm{Ti}, \mathrm{Mn}, \mathrm{Cr}, \mathrm{Ba}, \mathrm{Sr}, \mathrm{Zn}$, $\mathrm{Cu}, \mathrm{Ni}$ and $\mathrm{Pb}$ were determined using optical emission spectrometry with inductively coupled plasma (ICP OES) (8300-PerkinElmer) and Si by X-ray fluorescence (Medx1300-Shimadzu). The K content was determined by flame emission spectrophotometry (B462Micronal).

$\mathrm{K}$ soluble in water was determined in $1.0 \mathrm{~g}$ sample with particle size $<150 \mu \mathrm{m}$, which was transferred to a 125-ml Erlenmeyer flask and added of $50 \mathrm{~mL}$ of distilled water. The solution was boiled for $10 \mathrm{~min}$ in a heater plate at $180^{\circ} \mathrm{C}$. After cooling, the extract was filtered in slow quantitative filter paper $(>28 \mu \mathrm{m})$. The flasks were weighed before and after the boiling in order to correct the volume.

$\mathrm{K}$-soluble in $2 \%$ citric acid was determined in $0.50 \mathrm{~g}$ of sample with particle size $<150 \mu \mathrm{m}$, which was transferred to a 125-ml Erlenmeyer flask and added of $50 \mathrm{~mL}$ of the solution of $2 \%$ monohydrate

Table 1. Coordinate locations of the collection sites of the verdete rock samples, in the municipalities of Quartel Geral and Cedro do Abaeté, in Minas Gerais, Brazil

\begin{tabular}{lcc}
\hline \multirow{2}{*}{ Collection site } & \multicolumn{2}{c}{ Coordinate UTM (Fuse UTM 23 S) } \\
\cline { 2 - 3 } & $\mathbf{X}$ & $\mathbf{Y}$ \\
\hline 1 & 420763.1 & 7871570.4 \\
2 & 420763.1 & 7871570.4 \\
3 & 419654.6 & 7871575.9 \\
4 & 421120.1 & 7871937.6 \\
5 & 421136.3 & 7871929.0 \\
6 & 421142.7 & 7871878.0 \\
7 & 421843.8 & 7872863.6 \\
8 & 421873.2 & 7872788.0 \\
9 & 422032.9 & 7872736.5 \\
10 & 423725.6 & 7874215.9 \\
11 & 423738.8 & 7874334.6 \\
12 & 426090.9 & 7882653.2 \\
13 & 425888.3 & 7882636.0 \\
14 & 426728.6 & 7881766.5 \\
\hline
\end{tabular}

citric acid. The solution was stirred in a circular horizontal shaking table at $160 \mathrm{rpm}$ for $30 \mathrm{~min}$. The extract was filtered in slow quantitative filter paper (> $28 \mu \mathrm{m})$. The $\mathrm{K}$ content of the aqueous extract and citric acid was determined by flame emission spectrophotometry.

\section{Fractionation and sedimentation in water}

The relationship between particle size and the total concentration of $\mathrm{K}$ in the rock was evaluated in verdete rock samples chemically characterized with $\mathrm{K}$ content above $8.4 \mathrm{dag} / \mathrm{kg}$ of $\mathrm{K}_{2} \mathrm{O}$. A sample of $250 \mathrm{~g}$ of rock was milled and passed through a $2.0 \mathrm{~mm}$ sieve and separated into three size classes $(0.2-2.0 ; 0.15-0.2$ and $<0,15 \mathrm{~mm}$ ). Sedimented and suspended samples were also obtained in the $<0.15 \mathrm{~mm}$ fraction, in an aqueous medium. Twenty-five grams ( $25 \mathrm{~g})$ of this fraction were transferred to 1.0-L beakers and stirred at intervals of $120 \mathrm{~min}$ for a total of five cycles, when the suspended fraction was collected using a siphon. Finally, the material was dried in a forced air oven at $105{ }^{\circ} \mathrm{C}$. The trial was conducted in a completely randomized design with three replications.

A rock sample was ground to the size $<0.15 \mathrm{~mm}$ and used as a reference for the total concentration of $\mathrm{K}$.

\section{Mineralogical characterization}

The mineralogical analysis was carried out using Xray diffractometry (XRD). The samples were ground to a particle size $<0.15 \mathrm{~mm}$ and placed in excavated blade. A PHNalytical diffractometer model X' PertPRO, using CoK $\alpha$ radiation $(1.7889 \mathrm{~nm})$ with sample scanning in the range of 4 to 80 degrees $2 \theta$, with intervals from 0.02 degrees $2 \theta$ to 1 step. $^{-1}$; with $40 \mathrm{kV}$ voltage and $30 \mathrm{~mA}$ current.

\section{RESULTS}

Verdete rock occurs in the municipalities of Cedro do Abaeté and Quartel Geral between 880 and 940 m altitude. The samples showed intense color variation and hardness, indicating the different degrees of weathering. The K contents varied randomly in the landscape and were higher in the hardest rocks of more intense green, tending to blue (Figure 2).

The total $\mathrm{K}$ content in the rock varied between 5.18 and $9.0 \mathrm{dag} / \mathrm{kg}$, and the average solubility in water and $2 \%$ citric acid were 0.61 and $1.54 \%$ of the total $\mathrm{K}$, respectively (Table 2 ).

Table 3 shows the total content of some elements found in verdete rock. In addition to $\mathrm{K}$, the average contents of $62.64 \mathrm{dag} / \mathrm{kg}$ of $\mathrm{SiO}_{2}, 5.81 \mathrm{dag} / \mathrm{kg}$ of $\mathrm{Fe}_{2} \mathrm{O}_{3}$ and $14.43 \mathrm{dag} / \mathrm{kg}$ of $\mathrm{Al}_{2} \mathrm{O}_{3}$ also stand out. The rock is 
poor in $\mathrm{P}, \mathrm{Ca}, \mathrm{Mg}$ and $\mathrm{S}$ and has low levels of potentially toxic elements (Brasil, 2006). The contents of micronutrients $\mathrm{Zn}, \mathrm{Cu}$ and $\mathrm{Mn}$ in the rock are very low or zero.

The mineralogical characterization using diffraction with peaks at $1.0,0.5,0.453,0.363,0.333$, 2.396 and $1.511 \mathrm{~nm}$ indicates the occurrence of glauconite in all samples. The presence of quartz was diagnosed by peaks at $0.425,0.335,0.228$ and 0.214 $\mathrm{nm}$. Feldspars were recorded by the peaks at 0.574 , $0.426,0.404,0.379,0.348,0.335,0.324$ and $0.30 \mathrm{~nm}$ (Figure 3).

Physical fractionation of verdete rock, in different grain sizes, caused no significant changes in total $\mathrm{K}$ contents in relation to the content obtained from the reference sample (Figure 4).

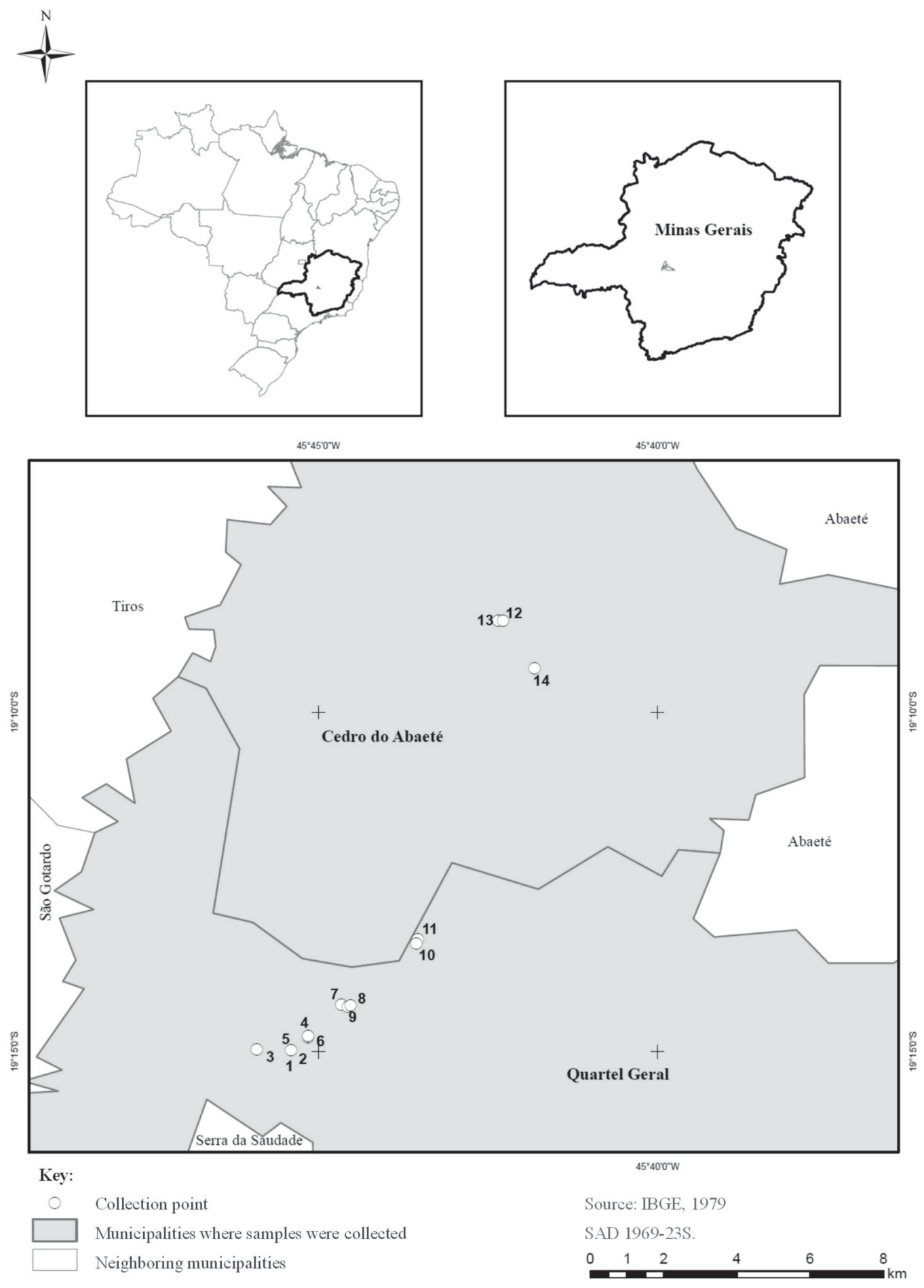

Figure 1. Location map of the collection sites of the verdete rock samples in the municipalities of Quartel Geral and Cedro do Abaeté, in Minas Gerais, Brazil. 


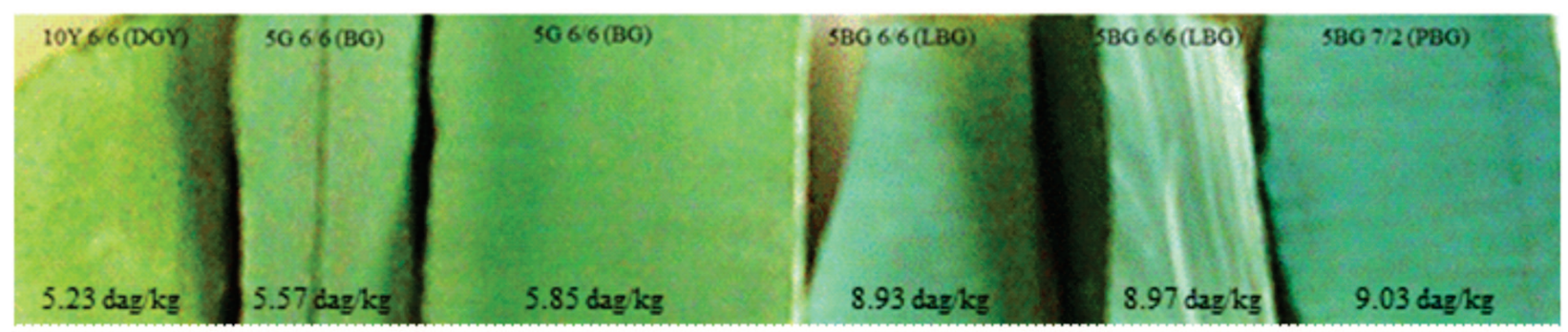

Figure 2. Photograph showing the variation in $\mathrm{K}_{2} \mathrm{O}$ content (values at the bottom) in verdete rock samples and changes in the rock color. Color classification according to Munsell Color (2009) (top). DGY (Dark Greenish Yellow), BG (Brilliant Green), LBG (Light Blue Green) and PBG (Pale Blue Green).

Table 2. $\mathrm{K}$ total contents and soluble in water and $2 \%$ citric acid in samples of verdete rock

\begin{tabular}{|c|c|c|c|}
\hline \multirow[t]{3}{*}{ Samples } & \multirow{3}{*}{$\begin{array}{c}\text { Total } \mathrm{K}_{2} \mathrm{O} \text { content } \\
\mathrm{dag} / \mathrm{kg}\end{array}$} & \multicolumn{2}{|c|}{ Solubility of verdete rock for $K$} \\
\hline & & water & $2 \%$ citric acid \\
\hline & & \multicolumn{2}{|c|}{$\%$} \\
\hline 1 & 5.23 & 0.26 & 1.22 \\
\hline 2 & 5.86 & 0.64 & 1.75 \\
\hline 3 & 8.43 & 0.56 & 1.96 \\
\hline 4 & 6.33 & 0.63 & 1.44 \\
\hline 5 & 5.57 & 1.37 & 1.61 \\
\hline 6 & 5.42 & 0.93 & 1.59 \\
\hline 7 & 8.11 & 1.00 & 2.29 \\
\hline 8 & 8.08 & 0.50 & 1.12 \\
\hline 9 & 8.93 & 0.25 & 1.00 \\
\hline 10 & 8.29 & 0.12 & 0.81 \\
\hline 11 & 7.52 & 0.15 & 0.67 \\
\hline 12 & 8.67 & 0.92 & 2.33 \\
\hline 13 & 9.04 & 0.34 & 1.13 \\
\hline 14 & 9.00 & 0.85 & 1.49 \\
\hline Lower & 5.22 & 0.12 & 0.67 \\
\hline Medium & 7.46 & 0.61 & 1.54 \\
\hline Higher & 9.00 & 1.37 & 2.33 \\
\hline D-standard & 1.45 & 0.37 & 0.58 \\
\hline
\end{tabular}

\section{DISCUSSION}

The variation in $\mathrm{K}$ contents of the verdete rock in relation to the green intensity may be due to glauconite weathering. This micaceous mineral rich in $\mathrm{K}$ (Maraschin \& Mizusaki, 2008), when weathered, undergoes initial changes which result in reduced load and loss of structural $\mathrm{K}$ (Curi et al., 2005), decreasing the $\mathrm{K}$ content in rock with the advance of weathering processes.

Variations in the green color of verdete rock may be related to the change in the relationship between $\mathrm{Fe}^{2+}$ and $\mathrm{Fe}^{3+}$, which participate in the rock formation. This element is in the octahedral layer of glauconite, replacing $\mathrm{Al}^{3+}$ isomorphically. The weathering and oxidation of $\mathrm{Fe}^{2+}$ cause the ratio $\mathrm{Fe}^{2+} / \mathrm{Fe}^{3+}$ to decrease, which could be an influential factor in defining the verdete rock color, which is independent of the total Fe content (Chiodi Filho et al., 2003), as confirmed by the results . The small changes in the levels of $\mathrm{Fe}$ and independence with the $\mathrm{K}$ content and the rock color confirm the statement by Chiodi Filho et al. (2003). Certainly the formation of minerals such as iron oxides during weathering of verdete rock immobilize the element in the rock. Data reported by Piza et al. (2011) confirm the presence of iron oxides in verdete rock samples. The same assumptions apply to $\mathrm{Al}$, which must remain in the system during the weathering of verdete minerals due to the formation of Al oxy-hydroxides.

According to Lima (2007), the green color of the verdete rock may vary with the particle size of the rock, and as particle size decreases the green color becomes more intense, indicating that the chromophore mineral is concentrated in the clay fractions.

The variation in total contents of $\mathrm{K}$ in verdete rock has also been observed in other studies. Eichler (1983) 
Table 3. Concentration of some elements in samples of verdete rock

Element concentration

\begin{tabular}{|c|c|c|c|c|c|c|c|c|c|c|c|c|c|c|c|c|c|c|}
\hline \multirow[t]{2}{*}{ Sample } & $\mathrm{K}_{2} \mathrm{O}$ & $\mathrm{SiO}_{2}$ & $\mathrm{Fe}_{2} \mathrm{O}_{3}$ & $\mathrm{Al}_{2} \mathrm{O}_{3}$ & $\mathrm{CaO}$ & MgO & $\mathrm{Na}_{2} \mathrm{O}$ & $\mathbf{P}_{2} \mathbf{O}_{5}$ & $\mathrm{TiO}_{2}$ & MnO & $\mathrm{Cr}_{2} \mathrm{O}_{3}$ & $\mathrm{BaO}$ & SrO & $\mathbf{S}$ & $\mathbf{Z n}$ & $\mathrm{Cu}$ & $\mathrm{Ni}$ & $\mathbf{P b}$ \\
\hline & \multicolumn{13}{|c|}{$\% \mathrm{w} / \mathrm{w}$} & \multicolumn{5}{|c|}{$\mathrm{mg} / \mathrm{kg}$} \\
\hline 1 & 5.23 & 61.13 & 6.70 & 16.25 & 0.62 & 1.13 & 0.21 & 0.00 & 0.74 & 0.00 & 0.01 & 0.07 & 0.01 & 400 & 90 & 91 & 10 & 42 \\
\hline 2 & 5.86 & 63.68 & 6.00 & 14.40 & 0.03 & 1.10 & 0.16 & 0.00 & 0.35 & 0.00 & 0.01 & 0.00 & 0.00 & 200 & 95 & 85 & 2 & 54 \\
\hline 3 & 8.43 & 62.56 & 5.46 & 14.42 & 0.35 & 1.08 & 0.18 & 0.00 & 0.57 & 0.01 & 0.01 & 0.02 & 0.00 & 400 & 94 & 88 & 3 & 47 \\
\hline 4 & 6.33 & 58.37 & 6.57 & 12.02 & 0.80 & 1.27 & 0.21 & 0.00 & 0.61 & 0.01 & 0.02 & 0.01 & 0.01 & 400 & 131 & 116 & 12 & 43 \\
\hline 5 & 5.57 & 65.61 & 5.63 & 14.96 & 0.00 & 1.20 & 0.14 & 0.00 & 0.70 & 0.00 & 0.02 & 0.03 & 0.00 & 200 & 87 & 190 & 7 & 29 \\
\hline 6 & 5.42 & 59.09 & 5.83 & 14.25 & 0.00 & 1.10 & 0.12 & 0.00 & 0.62 & 0.00 & 0.01 & 0.04 & 0.00 & 200 & 89 & 88 & 2 & 50 \\
\hline 7 & 8.11 & 62.42 & 5.67 & 14.62 & 0.38 & 1.20 & 0.22 & 0.05 & 0.57 & 0.00 & 0.02 & 0.05 & 0.00 & 300 & 117 & 92 & 7 & 35 \\
\hline 8 & 8.08 & 60.83 & 5.77 & 15.09 & 0.38 & 1.10 & 0.25 & 0.05 & 0.62 & 0.00 & 0.01 & 0.01 & 0.00 & 300 & 100 & 88 & 3 & 43 \\
\hline 9 & 8.93 & 65.63 & 5.74 & 15.06 & 0.01 & 1.22 & 0.20 & 0.07 & 0.63 & 0.00 & 0.01 & 0.01 & 0.01 & 200 & 100 & 94 & 7 & 39 \\
\hline 10 & 8.29 & 64.34 & 4.84 & 13.43 & 0.00 & 1.12 & 0.11 & 0.07 & 0.64 & 0.00 & 0.01 & 0.01 & 0.01 & 200 & 92 & 75 & 3 & 47 \\
\hline 11 & 7.52 & 60.91 & 6.20 & 15.30 & 0.76 & 1.22 & 0.23 & 0.07 & 0.64 & 0.01 & 0.01 & 0.00 & 0.02 & 300 & 123 & 100 & 11 & 48 \\
\hline 12 & 8.67 & 60.83 & 5.06 & 14.49 & 0.43 & 1.12 & 0.24 & 0.05 & 0.53 & 0.00 & 0.01 & 0.01 & 0.00 & 200 & 106 & 82 & 3 & 41 \\
\hline 13 & 9.04 & 65.25 & 6.13 & 14.02 & 0.04 & 1.25 & 0.15 & 0.02 & 0.60 & 0.01 & 0.01 & 0.00 & 0.00 & 200 & 133 & 102 & 14 & 39 \\
\hline 14 & 9.00 & 66.32 & 5.49 & 13.74 & 0.14 & 1.25 & 0.19 & 0.05 & 0.46 & 0.00 & 0.01 & 0.04 & 0.00 & 200 & 111 & 83 & 5 & 42 \\
\hline Lower & 5.23 & 58.37 & 4.84 & 3.43 & 0.00 & 1.08 & 0.11 & 0.00 & 0.35 & 0.00 & 0.01 & 0.01 & 0.00 & 200 & 87 & 75 & 2 & 29 \\
\hline Medium & 7.46 & 62.64 & 5.81 & 14.43 & 0.28 & 1.17 & 0.18 & 0.03 & 0.57 & 0.00 & 0.01 & 0.02 & 0.00 & 264 & 105 & 98 & 6 & 43 \\
\hline Higher & 9.04 & 66.32 & 6.70 & 16.25 & 0.80 & 1.27 & 0.25 & 0.07 & 0.74 & 0.01 & 0.02 & 0.05 & 0.02 & 400 & 133 & 190 & 14 & 54 \\
\hline D_standard & 1.50 & 2.60 & 0.50 & 1.00 & 0.30 & 0.10 & 0.00 & 0.00 & 0.10 & 0.00 & 0.00 & 0.00 & 0.00 & 84 & 16 & 28 & 4 & 6 \\
\hline
\end{tabular}


reported mean content of the element in rock of 11.4 $\mathrm{da} / \mathrm{kg}$, whereas Piza et al. (2010) found $\mathrm{K}_{2} \mathrm{O}$ ranging between 6.09 and $7.33 \mathrm{dag} / \mathrm{kg}$.

Verdete rock has low content of $\mathrm{K}$ soluble in water or $2 \%$ citric acid, indicating a certain limitation to the use as potassium fertilizer in its natural state, especially for short cycle crops. However, the total $\mathrm{K}$ content, of up to $9.0 \mathrm{dag} / \mathrm{kg} \mathrm{K}_{2} \mathrm{O}$, indicate the potential use of the rock as raw material for the production of potash fertilizer.
Low concentration of other macronutrients of agronomic interest in verdete rock such as $\mathrm{P}, \mathrm{Ca}, \mathrm{S}, \mathrm{Mg}$ and the micronutrients, $\mathrm{Zn}, \mathrm{Cu}$ and $\mathrm{Mn}$ limit the use of this rock for exploitation of these elements or as fertilizer, since abundant and more concentrated sources are found in the country (Betekhine, 1968; Sampaio et al., 2005; CETEM, 2009).

The mineralogical characteristics of the verdete rock samples show similar composition of those reported by Piza et al. (2011). According to these authors, this rock

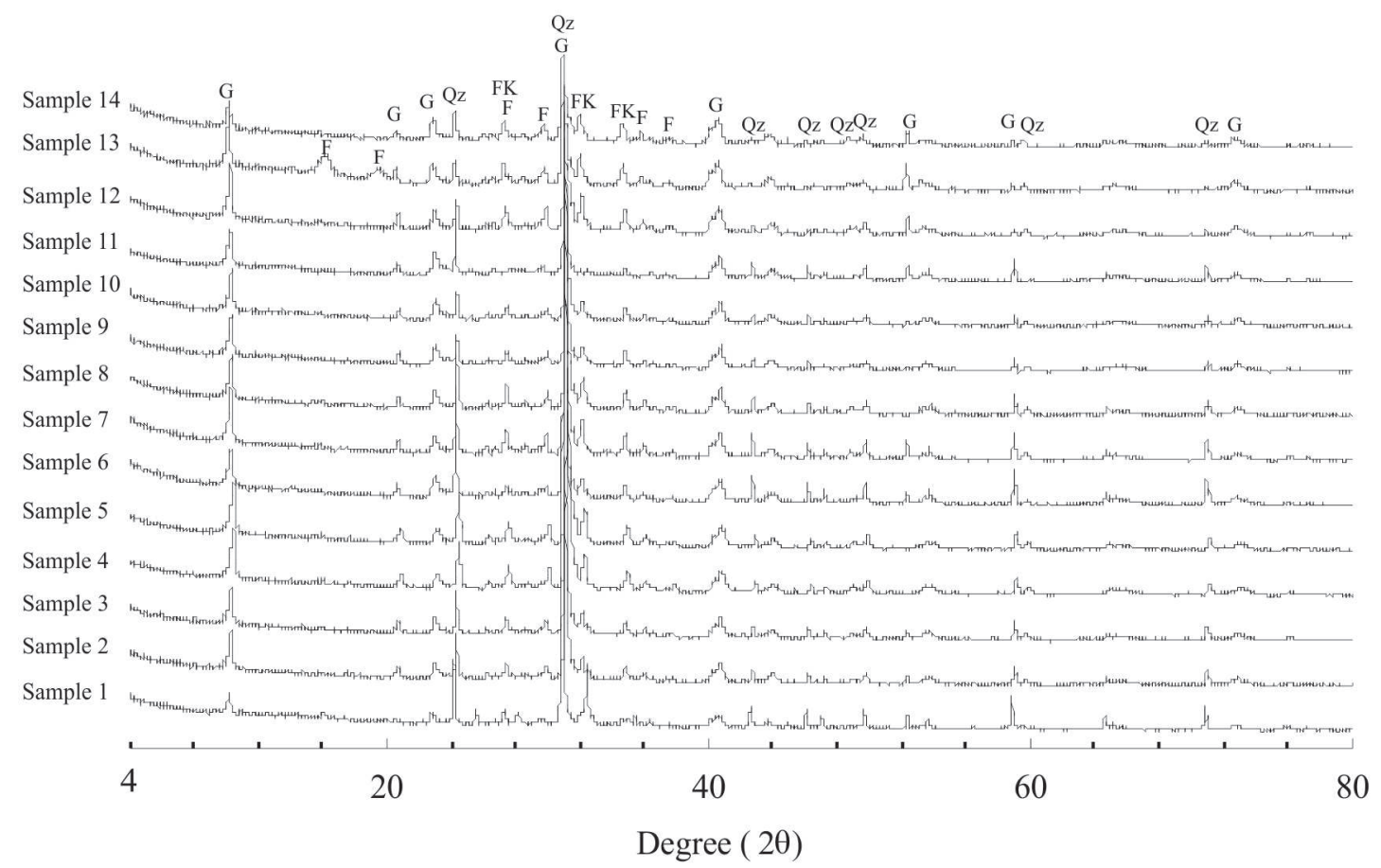

Figure 3. X-ray diffractograms of verdete rock samples, with cobalt radiation (1.7889 nm), scanning at 4-80 degrees (20). G: glauconite; Qz: quartz; F: feldspar; and FK: potassium feldspar.

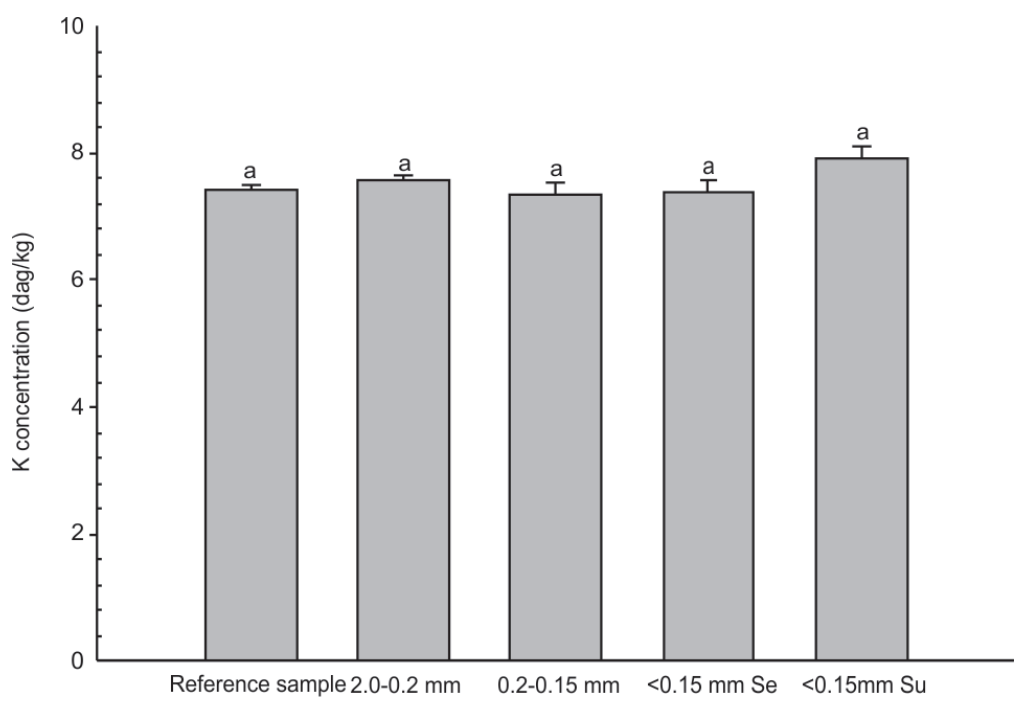

Figure 4. Total $\mathrm{K}$ contents in verdete rock (reference), in the size fractions between 2.0 and $0.2 \mathrm{~mm}$; between 0.2 and $0.15 \mathrm{~mm}$; less than $0.15 \mathrm{~mm}$ sedimented (Se) and less than $0.15 \mathrm{~mm}$ suspended ( $\mathrm{Su}$ ). Means followed by the same letter in the columns are not significantly different by the Tukey test at $5 \%$ probability. (I) represents the standard error of the mean. 
contains on average $37 \%$ of glauconite, $24 \%$ quartz, $14 \%$ of light-brown clay matrix, $11 \%$ kaolinite, $7 \%$ iron oxides, $7 \%$ of muscovite and occurrence of feldspar. The occurrence of other potassic minerals in, such as vermiculite, chlorite and illite was also reported (Silva et al., 2012; Piza et al., 2010).

The concentration of $\mathrm{K}$ through physical fractionation was not achieved, certainly because the process was not able to separate quartz from glauconite. It is believed that the rock has great homogeneity in the distribution of minerals, thus these are broken in the same size by grinding and the separation by sieving or sedimentation is not possible. These results are in line with the study by Soni (1990), who tested a similar process to concentrate $\mathrm{K}$ from glauconitic sandstones. This author argues that the physical separation of glauconite, mainly from quartz, the second most abundant mineral in verdete rock (Piza et al., 2011), is not achievable through gravimetric processes because of the large variation in glauconite density, between 2.4 and $2.9 \mathrm{~g} / \mathrm{cm}^{3}$, coinciding with the quartz density, around $2.65 \mathrm{~g} / \mathrm{cm}^{3}$. However, Piza et al. (2011), after the granulometric analysis of verdete rock, observed with a binocular microscope that the quartz is separated from glauconite starting from the granulometric fraction below $0.105 \mathrm{~mm}$. However, these authors found low concentrations of $\mathrm{K}$ in the fractions. Mazumder et al. (1993) state that glauconite is completely separated from other minerals in glauconitic sandstones starting from fractions with particle size $<0.15 \mathrm{~mm}$.

\section{CONCLUSIONS}

Potassium contents vary markedly between verdete rock samples and are higher in rocks less weathered, harder and of more intense green, tending to blue. acid.

Verdete rock has low reactivity in water or $2 \%$ citric

Glauconite and feldspars are the crystalline mineral sources of $\mathrm{K}$ in verdete rock.

Although physical fractionation and sedimentation in water have proven ineffective processes for the concentration of $\mathrm{K}$ from verdete rock, their total $\mathrm{K}$ contents are promising for the development processes of solubilizing or concentration of $\mathrm{K}$.

\section{REFERENCES}

Betekhine A(1968) Manuel de mineralogie descriptive. Moscou, Editons MIR. 735p.

BRASIL (2006) Ministério da Agricultura Pecuária e Abastecimento. Instrução Normativa SDA No 27, de 05 de junho de 2006. Dispõe sobre as concentrações máximas admitidas para agentes fitotóxicos, patogênicos ao homem, animais e plantas, metais pesados tóxicos, pragas e ervas daninhas. Brasília, Diário Oficial da União. p.15- 16.
CETEM - Centro de Tecnologia de Produção Mineral (2009) Anuário mineral. Séries históricas do setor mineral brasileiro. Disponível em: <http:// http://www.cetem.gov.br>. Acessado em: 27 de junho de 2013.

Chiodi Filho C, Rodrigues EP \& Artur AC (2003) Ardósias de Minas Gerais, Brasil: Características geológicas, petrográficas e químicas. Revista Brasileira de Geociências, 22:119-127.

Curi N, Kampf N \& Marques JJ (2005) Mineralogia e formas de potássio em solos brasileiros. In: Yamada T \& Roberts TL (Eds.) Potássio na agricultura brasileira. Piracicaba, Potafos. p.71-91.

Eichler V (1983) Disponibilidade do potássio do verdete de Abaeté, calcinado com e sem calcário magnesiano, para a cultura do milho (Zea mays L.), em solos de textura média e argilosa. Tese de Mestrado. Escola Superior de Agricultura de Lavras, Lavras. 122p.

EPA - Environmental Protection Agency (1996) Microwave assisted acid digestion of siliceous and organically based matrices. Method 3052. Disponível em: <http://www.epa.gov/solidwaste/hazard/ testmethods/sw846/pdfs/3052.pdf $>$. Acessado em: 27 de junho de 2013.

Faquin V (1982) Efeito do tratamento térmico do sienito nefelínico adicionado de calcário dolomítico, na disponibilidade de potássio ao milho (Zea mays L.), em casa de vegetação. Tese de Mestrado. Escola Superior de Agricultura "Luiz de Queiroz", Piracicaba. 115p.

Fassbender HW (1975) Química de suelos. Turrialba, IICA. 398p.

Fertecon (2013) Market Analysis Reports. Disponível em: <http:// fertecon.com/market_analysis_reports.asp >. Acessado em: 24 de janeiro de 2013.

Guimarães D (1997) Ocorrência de fosforita no município de Abaeté, Minas Gerais. DNPM-DGM. Notas preliminares e estudos. 18p.

IFA (2013) International Fertilizer Industry Association. Production and trade. Disponível: <http://www.fertilizer.org/ifa/HomePage/ STATISTICS/Production-and-trade>. Acessado em: 24 de janeiro de 2013.

Lawless AS (2012) Nature, distribution, origin and economics of glauconite in carbonate-phosphate-glauconite surficial deposits on Central Chatham Rise, Southwest Pacific. Tese de mestrado. The University of Waikato, Waikato. 279p.

Leite P (1985) Efeitos de tratamentos térmicos em misturas de verdete de Abaeté, fosfato de Araxá e calcário magnesiano, na disponibilidade de potássio e fósforo. Tese de Mestrado. Escola Superior de Agricultura de Lavras, Lavras. 146p.

Lima ONB, Uhlein A \& Britto W (2007) Estratigrafia do Grupo Bambuí na Serra da Saudade e geologia do depósito fosfático de Cedro do Abaeté, Minas Gerais. Revista Brasileira de Geociências, 37:204-215.

Lopes AS, Freire JC, Aquino LH \& Felipe MP (1972) Contribuição ao estudo da rocha potássica - Verdete de Abaeté (Glauconita) para fins agrícolas. Agros, 2:32-42.

Loureiro FEL, Nascimento M, Neumann R \& Rizzo AC (2010) Tecnologias de aplicação de Glauconita como fonte de potássio na agricultura: o caso brasileiro e a experiência indiana. In: I Congresso Brasileiro de Rochagem, Planaltina. Anais, EMBRAPA Cerrados. p.111-119.

Maraschin AJ \& Mizusaki AM (2008) Datação de processos diagenéticos em arenitos-reservatório de hidrocarbonetos: uma revisão conceitual. Revista Pesquisas em Geociências, 35:27-41.

Mazumder AK, Sharma T \& Rao TC (1993) Extraction of potassium from glauconitic sandstone by the roast-leach method. International Journal of Mineral Processing, 38:111-123.

Nascimento M (2004) Desenvolvimento de método para extração de potássio a partir de feldspato potássico. Dissertação de Doutorado. Universidade Federal do Rio de Janeiro, Rio de Janeiro. 113p.

Oliveira LAM \& Souza AE (2001) Potássio. In: Balanço Mineral Brasileiro. Brasília, DNPM/SE. p.01-17. 
Oliveira LAM (2012) Potássio. In: Sumário Mineral. Brasília, DNPM/SE. p.99-100.

Orioli Júnior V \& Coutinho ELM (2009) Eficiência do termofosfato magnesiano potássico para o capim-marandu. Revista Brasileira de Ciência do Solo, 33:1855-1862.

Pettijohn FJ (1963) Rocas sedimentárias. Buenos Aires, Universidade de Buenos Aires. 731p

Piza PAT, Bertolino LC, Silva AAS, Sampaio JA \& Luz AB (2011) Verdete da região de Cedro do Abaeté (MG) como fonte alternativa para potássio. Geociências. UNESP, 30:345-356.

Piza PAT, França SCA \& Bertolino LC (2010) Caracterização mineralógica de fontes alternativas para potássio. Disponível em: <http:// www.cetem.gov.br/publicacao/serie_anais.pdf $>$. Acessado em: $23 \mathrm{de}$ agosto de 2012.

Rao BR, Majumder AK \& Rao TC (1993) Fluoride aided potassium extraction from glauconitic sandstone for liquid fertilizer. Minerals Engineering, 6:405-413.

Rawlley RK (1994) Mineralogical investigations on an Indian glauconitic sandstone of Madhya Pradesh state. Applied Clay Science, 8:449 465 .
Sampaio JA, Andrade MC, Dutra AJB \& Penna MTM (2005) Manganês. In: Luz AB da, Lins FF (Eds.) Rochas \& Minerais Industriais: Usos e Especificações. Rio de Janeiro, CETEM-MCT. p.515-530.

Santos EA (1984) Efeito da acidificação do verdete de Abaeté na disponibilidade de potássio para o milho (Zea mayz L.) em casa-de-vegetação. Tese de Mestrado. Escola Superior de Agricultura de Lavras, Lavras. 113p.

Soni MK (1990) On the possibility of using glauconite sandstone as a source of raw material for potash fertilizer. Mining and Engineering Journal, 1:3-10.

Silva AAS, Medeiros ME, Sampaio JA \& Garrido FMS (2012) Verdete de Cedro do Abaeté como fonte de potássio: caracterização, tratamento térmico e reação com CaO. Revista Matéria, 17:1062-1074.

Siqueira JO \& Guedes GAA (1986) Efeito do tratamento térmico na eficiência agronômica do sienito sefelínico. Pesquisa Agropecuária Brasileira, 21:481-488.

Valarelli JV, Novais RF, Melo MTV \& Leal ED (1993) Ardósias "Verdete" de Cedro do Abaeté na Produção de Termofosfato Potássico Fundido e sua Eficiência Agronômica.Anais da Academia Brasileira de Ciências, 65:363-375. 